\title{
ANALISIS KEMUNGKINAN DAMPAK KETERLIBATAN INDONESIA DALAM TRANS PACIFIC PARTNERSHIP (TPP) TERHADAP KINERJA PERDAGANGAN DAN DAYA SAING EKSPOR
}

\author{
Markhatin Nurul Latifah, Akhmad Akbar Susamto \\ Institute of Public Policy and Economic Studies \\ Bulaksumur, Caturtunggal, Depok, Sleman, Daerah Istimewa Yogyakarta 55281, \\ Indonesia \\ E-mail Korespondensi: markhatinlatif@ymail.com
}

Naskah Diterima: Januari 2016; Disetujui: April 2016

\begin{abstract}
The Trans Pacific Partnership (TPP) is the largest economic cooperation agreement in the Asia Pacific region. Some countries are considering the decision to join this multilateral cooperation. This study aims to analyze the possible impact of Indonesian involvement in TPP on trade performance and export competitiveness. This became one of the contributions in the development of Islamic economic studies considering the purpose of this study is to formulate effective policies to realize a prosperous society selatas with maqashid shariah. The analysis in this research is done by simulating the free trade policy of Indonesia-TPP using Analytical tool of Global Trade Analysis Project (GTAP) version 8. The result of the analysis shows the impact of the decline of Indonesian trade performance in general. Indonesia's export competitiveness is measured using Revealed Symmetric Comparative Advatage (RSCA) and Trade Balance Index (TBI) to identify Indonesia's export commodities that have comparative and competitive advantages in the world market. By mapping the commodity into product mapping can be seen some of Indonesia's superior commodities in the world market.
\end{abstract}

Keywords: Computable General Equilibrium Models, economic integration, trade forecasting, Trans Pacific Partnership (TPP).

JEL Classification: F43, P45

Abstrak: The Trans Pacific Partnership (TPP) merupakan suatu kesepakatan kerja sama ekonomi terbesar di kawasan Asia Pasifik. Beberapa negara tengah mempertimbangkan keputusan untuk bergabung dalam kerja sama multilateral ini. Penelitian ini bertujuan untuk menganalisis kemungkinan dampak keterlibatan Indonesia dalam TPP terhadap kinerja perdagangan dan daya saing ekspor. Hal ini menjadi salah satu kontribusi dalam pengembangan studi ekonomi Islam mengingat tujuan dari penelitian ini adalah untuk merumuskan kebijakan efektif agar terwujud masyarakat yang sejahtera selatas dengan maqashid syariah. Analisis dalam penelitian ini dilakukan dengan melakukan simulasi kebijakan perdagangan bebas Indonesia-TPP menggunakan alat analisis Global Trade Analysis Project (GTAP) versi 8. Hasil analisis menunjukkan dampak turunnya kinerja perdagangan Indonesia secara umum. Daya saing ekspor Indonesia diukur menggunakan Revealed Symmetric Comparative Advatage (RSCA) dan Trade Balance Index (TBI) sehingga dapat diidentifikasi komoditas ekspor Indonesia yang memiliki keunggulan komparatif dan berdaya saing di pasar dunia. Dengan memetakan komoditas ke dalam product mapping dapat dilihat beberapa komoditas unggulan Indonesia di pasar dunia.

Kata kunci: Model Ekuilibrium Umum Komputasi, integrasi ekonomi, peramalan dan simulasi perdagangan, Trans Pacific Partnership (TPP).

Klasifikasi JEL: F43, P45 


\section{PENDAHULUAN}

Globalisasi yang semakin berkembang menuntut setiap negara untuk meningkatkan keterbukaan ekonominya dengan negara lain, salah satunya adalah melalui kegiatan perdagangan internasional. Isu yang selalu berkembang dalam perdagangan internasional adalah peningkatan liberalisasi dengan menghapuskan berbagai hambatan perdagangan. Pengurangan atau bahkan penghapusan hambatan dalam perdagangan internasional ini dilakukan dengan berbagai skema, dan hanya berlaku bagi negara-negara yang bersepakat melalui perjanjian dalam suatu kerja sama internasional, baik itu bilateral, regional maupun multilateral.

Salah satu kesepakatan perdagangan bebas yang baru saja disepakati di kawasan AsiaPasifik dan tengah menjadi isu hangat barubaru ini adalah Trans Pacific Partnership (TPP). Sejumlah negara di kawasan Asia Pasifik tengah mengkaji dan mempertimbangkan keputusan untuk bergabung dengan kerja sama multilateral ini. Kerja sama multilateral TPP merupakan yang paling besar di dunia. Tercatat, aktivitas ekonomi di antara negaranegara anggota TPP mencapai sekitar 40 persen Produk Domestik Bruto (PDB) dunia, dengan pelaku ekonomi 10 persen dari total populasi dunia, serta 20 persen dari total perdagangan dunia (Aichele \& Felbermayr, 2015). Hal ini menjadi salah satu daya tarik tersendiri bagi negara-negara di kawasan Asia Pasifik untuk bergabung dalam TPP.

Wacana mengenai komitmen Indonesia untuk bergabung dengan TPP telah disampaikan oleh Presiden Joko Widodo kepada Presiden Amerika Barack Obama ketika berkunjung ke Amerika Serikat pada tanggal 27 Oktober 2015 (Wangke, 2015). Keputusan Indonesia untuk bergabung dengan TPP ini telah menuai banyak perdebatan. Argumen yang mendukung Indonesia untuk bergabung ke dalam TPP adalah agar Indonesia dapat memperluas akses pasar ke negara-negara anggota TPP dan menjadi negara tangguh. Namun di sisi lain, Indonesia dinilai belum siap untuk bergabung dengan TPP karena dikhawatirkan hanya akan menjadi sasaran pasar bagi negara-negara anggota disebabkan daya saing produk Indonesia yang masih rendah.

Pengkajian isu tersebut merupakan suatu kontribusi dalam pengembangan studi ekonomi islam. Kajian ekonomi Islam dimaksudkan untuk membantu mewujudkan kesejahteraan manusia melalui alokasi dan distribusi sumber-sumber daya sesuai dengan maqashid syariah maka telah dirumuskan beberapa tugas ekonomi Islam. Pertama, yaitu mempelajari perilaku manusia sebagaimana adanya. Kedua, adalah menunjukkan jenis perilaku yang diperlukan bagi pencapaian tujuan. Ketiga, menjelaskan mengapa pranata ekonomi yang berbeda berperilaku sebagaimana adanya, dan bukan sebagaimana yang seharusnya. Keempat, yakni menyarankan suatu strategi yang dapat dilaksanakan dengan adanya perubahan sosial ekonomi dan politik, yang dapat membantu mengarahkan semua pelaku pasar untuk mengalokasikan dan mendistribusikan sumber daya untuk merealisasikan tujuan (Chapra, 2000).

Berpijak dari hal tersebut, penelitian ini menjadi penting dalam pengembangan studi ekonomi Islam khususnya pada aspek perdagangan dan kerja sama ekonomi internasional. Pertama, Indonesia merupakan negara dengan mayoritas penduduknya beragama Islam terbesar di dunia, berdasarkan data BPS yakni sekitar 207,18 juta jiwa di tahun 2010. Kedua, tujuan dari penelitian ini adalah menganalisis dampak yang mungkin terjadi apabila Indonesia terlibat dalam Trans Pacific Partnership (TPP) sehingga nantinya dapat dirumuskan kebijakan terbaik untuk menghadapi kemungkinan tersebut agar terwujud kesejahteraan masyarakat yang selaras dengan maqashid syariah. 


\section{METODE PENELITIAN}

\section{Jenis dan Sumber Data}

Secara keseluruhan, penelitian ini menggunakan data sekunder dari Global Trade Analysis Project (GTAP) versi 8 dengan tahun dasar 2007 yang diproduksi oleh Purdue University, USA. Database GTAP versi 8 ini terdiri dari 57 sektor komoditas dan meliputi 129 negara/region.

\section{Tahapan Penelitian}

Tahapan analisis menggunakan GTAP adalah sebagai berikut:

Melakukan agregasi data dari perangkat lunak GTAPAgg yaitu agregasi 3 region yakni: Indonesia; negara-negara anggota TPP (Austalia, Brunei Darussalam, Canada, Japan, Malaysia, Mexico, New Zealand, Peru, Singapore, United States, dan Vietnam). Dalam database GTAP versi 8, data negara Brunei Darussalam tidak tersedia, mengingat Brunei Darussalam merupakan salah satu negara anggota Trans Pacific Partnership (TPP). Oleh karena itu, agregasi dalam penelitian ini menggunakan variabel Rest of Southeast Asia untuk mewakili negara Brunei Darussalam.

Rest of The World (negara-negara selain Indonesia dan anggota TPP)

Sementara itu, agregasi 57 komoditas dalam GTAPAgg diagregasikan satu per satu, tetapi analisis dalam penelitian ini akan dikelompokkan menjadi 9 sektor utama, yakni sektor pertanian, peternakan, kehutanan dan perikanan; sektor pertambangan dan penggalian; sektor industri pengolahan; sektor listrik, gas dan air bersih; sektor bangunan; sektor perdagangan, hotel dan restoran; sektor pengangkutan dan komunikasi; sektor keuangan, persewaan dan jasa perusahaan; serta sektor jasa-jasa.

Hasil dari agregasi data yang telah dilakukan selanjutnya disimpan sebagai sumber data untuk analisis selanjutnya.

Mengolah (Running) data yang telah diagregasikan menggunakan RunGTAP 3.55 yang meliputi langkah-langkah sebagai berikut:

Menentukan variabel yang digunakan dalam model menjadi variabel endogen atau variabel eksogen.

Memberikan shock pada variabel eksogen. Shock yang digunakan dalam penelitian ini adalah variabel tms. Variabel tms merupakan salah satu variabel eksogen yang didefinisikan sebagai perubahan pajak/tarif impor untuk komoditas $i$ dari suatu region $r$ ke region $s$. Dalam hal ini, perlu diperhatikan jenis shock yaitu percentage change rate, percentage change power dan percentage target. Penelitian ini menerapkan percentage change rate dalam simulasi kebijakan full liberalisation dengan menghilangkan/mengenolkan tarif impor bilateral untuk seluruh sektor (change rate=$100 \%$ ) dari Indonesia ke TPP dan dari TPP ke Indonesia. Meskipun hal ini tidak dapat menggambarkan sepenuhnya keadaan dari skema Trans Pacific Pacific (TPP), tetapi simulasi ini dapat memberikan gambaran liberalisasi perdagangan Indonesia-TPP.

Hasil yang diperoleh lalu diberikan solusi dengan pendekatan Gragg dengan ekstrapolasi melalui 3 solusi. Pendekatan Gragg memiliki akurasi yang lebih tinggi dibandingkan dengan pendekatan Euler dan pendekatan Johansen karena pendekatan Gragg memiliki tahapan yang lebih banyak.

Melakukan analisis dari hasil simulasi yang telah dilakukan.

Keputusan Indonesia untuk terlibat dalam Trans Pacific Partnership (TPP) akan berpengaruh juga pada kondisi perdagangan Indonesia. Salah satu indikator yang dapat menunjukkan hal ini adalah neraca perdagangan. Indikator neraca perdagangan kemudian akan dijelaskan lebih rinci lagi pada komponen kinerja perdagangan, dengan melihat perubahan agregat ekspor dan agregat impor Indonesia ke dunia setelah simulasi kebijakan. Selanjutnya, apabila Indonesia terlibat dalam Trans Pacific Partnership (TPP), hal penting untuk dianalisis adalah mengenai dampaknya terhadap daya saing ekspor 
Indonesia yang direpresentasikan oleh keunggulan komparatif pada masing-masing komoditas.

\section{RCA dan RSCA}

Keunggulan komparatif menunjukkan kemampuan suatu negara untuk memproduksi suatu barang/jasa dengan opportunity cost yang lebih rendah dibandingkan dengan negara lain. Analisis empiris yang umum digunakan untuk meneliti pola keunggulan komparatif adalah Revealed of Comparative Advantage (RCA). Perhitungan indeks RCA oleh (Vollrath, 1991:36) mengukur gambaran relatif dari ekspor negara di suatu komoditas apabila dibandingkan dengan gambaran rata-rata dari komoditas tersebut dalam total perdagangan dunia. Indeks RCA yang juga sering disebut dengan Balassa Index diformulasikan sebagai:

$$
R C A_{i j}=\left(x_{i j} / x_{i n}\right) /\left(x_{r j} / x_{r n}\right)
$$

Formulasi tersebut menunjukkan $\mathrm{RCA}_{\mathrm{ij}}$ adalah pengungkapan komparatif dari negara $\mathrm{i}$ untuk kelompok komoditas $\mathrm{j}$ dan $\mathrm{x}_{\mathrm{ij}}$ adalah total ekspor negara i dalam kelompok komoditas j. $r$ menunjukkan semua negara kecuali negara i dan $\mathrm{n}$ menunjuk kepada semua kelompok komoditas kecuali kelompok komoditas j. Indeks dapat menggambarkan perbandingan dari struktur ekspor nasional (pembilang) dengan struktur ekspor dunia (penyebut). Adanya peniadaan komoditas negara dan kelompok di bawah pertimbangan, perhitungan ganda dapat dihindari dan sifat perdagangan yang selalu terjadi perdagangan komoditas secara bilateral di antara dua negara dalam digambarkan dengan baik (Worz, 2005; Vollrath, 1991). Nilai dari indeks berkisar dari 0 sampai tidak terhingga $\left(0 \leq \mathrm{RCA}_{\mathrm{ij}} \leq \infty\right)$. Apabila $\mathrm{RCA}_{\mathrm{ij}}$ lebih besar daripada 1 menunjukkan bahwa negara i memiliki keunggulan komparatif dalam kelompok komoditas j. Sebaliknya, jika $\mathrm{RCA}_{\mathrm{ij}}$ kurang dari 1 berarti negara i tidak memiliki keunggulan komparatif (comparative disadvantage) di komoditas $\mathrm{j}$.

Indeks RCA atau Balassa Index lalu mendapatkan kritik bahwa distribusi dari RCA tidak dapat diambil secara teoritis. Hal tersebut terjadi karena $\mathrm{RCA}_{\mathrm{ij}}$ memunculkan nilai yang tidak dapat dibandingkan pada kedua sisi dari 1, sehingga indeks tersebut perlu dibuat menjadi simetris. Oleh karena itu digunakanlah indeks baru yang disebut dengan Revealed Symmetric Advantage (RSCA) yang diformulasikan sebagai berikut (Laursen, 2000):

$$
R S C A_{i j}=\left(R C A_{i j}-1\right) /\left(R C A_{i j}+1\right)
$$

Indeks RSCA $_{\mathrm{ij}}$ berkisar dari -1 sampai +1 (atau $-1 \leq \mathrm{RSCA}_{\mathrm{ij}} \leq 1$ ). Intepretasi RSCA serupa dengan RCA. RSCA $\mathrm{ij}_{\mathrm{ij}}$ lebih besar dari 0 menunjukkan bahwa negara i memiliki keunggulan komparatif dalam komoditas $\mathrm{j}$ dan RSCA $_{i j}$ kurang dari 0 berarti bahwa negara $i$ tidak memiliki keunggulan komparatif (comparative disadvantage) dalam komoditas j.

\section{Trade Balance Index (TBI)}

Trade Balance Index (TBI) digunakan untuk menganalisis apakah negara memiliki spesialisasi dalam ekspor (net-exporter) atau impor (net-importer) untuk kelompok komoditas tertentu. TBI diformulasikan sebagai berikut.

$$
T B I_{i j}=\left(x_{i j}-m_{i j}\right) /\left(x_{i j}+m_{i j}\right)
$$

Berdasarkan formula tersebut, TBI menunjukkan trade balance index negara i untuk kelompok komoditas $\mathrm{j}$; $\mathrm{x}_{\mathrm{ij}}$ dan $\mathrm{m}_{\mathrm{ij}}$ masingmasing menggambarkan ekspor dan impor kelompok komoditas j dari negara i. Nilai dari kisaran indeks dari $-1 \mathrm{ke}+1$. TBI sama dengan -1 apabila sebuah negara hanya mengimpor. Sebaliknya, TBI sama dengan +1 apabila sebuah negara hanya mengekspor. Sementara indeks tidak terdefinisi ketika tidak ekspor dan impor. Peletakan nilai 0 pada kelompok komoditas memperlihatkan bahwa berpotensi untuk menjadi ekspor atau impor. Nilai dalam -1 dan +1 menunjukkan bahwa negara mengekspor dan mengimpor secara bersama-sama. Negara didefinisikan sebagai "net-importer" dalam kelompok komoditas tertentu ketika nilai TBI adalah negatif dan sebagai "net-exporter" ketika 
nilai TBI positif.

\section{Product Mapping}

Product Mapping dikembangkan oleh Widodo (2009) untuk menentukan pola konsep flying geese. Berdasarkan penghitungan Revealed Symmetric Comparative Advantage (RSCA) dan Trade Balance Index (TBI), maka dibangunlah alat analisis untuk mengombinasikannya dengan menggunakan panel flying geese dengan membuat kategori komoditas yang diekspor.

\begin{tabular}{|c|c|}
\hline $\begin{array}{c}\text { Grup B: } \\
\text { Keunggulan } \\
\text { Komparatif } \\
\text { Net-importer } \\
(\text { RSCA }>0 \text { dan } \mathrm{TBI}<0)\end{array}$ & $\begin{array}{c}\text { Grup A: } \\
\text { Keunggulan Komparatif } \\
\text { Net-exporter } \\
(\text { RSCA }>0 \text { dan } \mathrm{TBI}>0)\end{array}$ \\
\hline $\begin{array}{c}\text { Grup D: } \\
\text { Tidak Memiliki } \\
\text { Keunggulan } \\
\text { Komparatif } \\
\text { Net-importer } \\
\text { (RSCA<0 dan TBI<0) }\end{array}$ & $\begin{array}{c}\text { Grup C: } \\
\text { Tidak Memiliki } \\
\text { Keunggulan Komparatif } \\
\text { Net-exporter } \\
(\text { RSCA<0 dan TBI>0) }\end{array}$ \\
\hline
\end{tabular}

TBI $<0$

TBI $>0$

Sumber: (Widodo, 2010)

\section{Gambar 1. Product Mapping}

Flying geese dalam hal ini merupakan komoditas dan alat analisisnya disebut dengan "product mapping". Gambar 1 menunjukkan bagan product mapping yang dapat digunakan untuk mengkategorikan leading exported product menjadi dua sisi, sisi pertama pertama adalah terkait apakah suatu negara memiliki keunggulan komparatif atau tidak dan sisi kedua terkait dengan apakah suatu negara menjadi negara pengekspor atau pengimpor.

Dalam penelitian ini, untuk menghitung Revealed Symmetric Comparative Advantage (RSCA) dan Trade Balance Index (TBI), digunakan data yang bersumber dari database GTAP versi 8, yakni variabel VIMS yang mempresentasikan nilai impor komoditas $i$ dari region $r$ ke region $s$ pada tingkat harga domestik. Dua titik tahun yang digunakan adalah database GTAP versi 8 sebelum simulasi dan upadated data yang merupakan output yang dihasilkan setelah simulasi. Analisis yang digunakan adalah pendekatan shift yakni dengan melihat pola pergeseran dari penghitungan Revealed Symmetric Comparative Advantage (RSCA) dan Trade Balance Index (TBI) di antara kedua titik tahun tersebut.

\section{HASIL DAN PEMBAHASAN}

Indikator makroekonomi yang dijelaskan dalam penelitian ini adalah neraca perdagangan. Dengan terlibatnya Indonesia dalam Trans Pacifc Partnership (TPP), neraca perdagangan Indonesia diprediksi akan turun sebesar 833,693 juta dolar Amerika. Hal tersebut juga akan berdampak pada meningkatnya defisit neraca perdagangan pada negara-negara Trans Pacifc Partnership (TPP), tetapi dampaknya tidak lebih besar dibanding Indonesia karena diprediksikan sebesar 286,278 juta dolar Amerika. Sementara itu, neraca perdagangan Rest of The World (ROW) justru akan meningkat sebesar 1119,970 juta dolar Amerika.

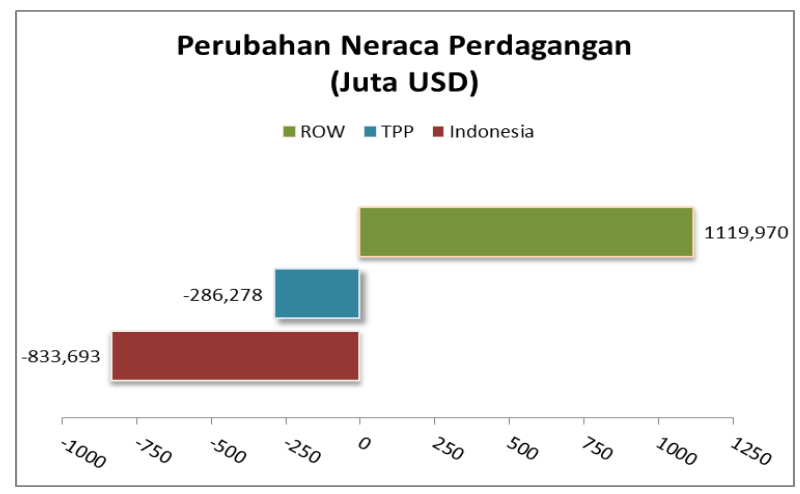

Sumber: GTAP versi 8, diolah

Gambar 2. Kemungkinan Dampak Keterlibatan Indonesia dalam TPP terhadap Neraca Perdagangan

Perubahan yang terjadi dalam neraca perdagangan Indonesia selanjutnya dijelaskan oleh kinerja perdagangan Indonesia di pasar dunia. Analisis tersebut dilakukan dengan melihat perubahan agregat ekspor dan agregat impor Indonesia di pasar dunia, meliputi 57 komoditas yang dikelompokkan ke dalam 9 sektor utama. 


\section{Kemungkinan Dampak Keterlibatan} Indonesia dalam Trans Pacific Partnership (TPP) terhadap Kinerja Perdagangan Indonesia

Apabila Indonesia terlibat di dalam kesepakatan Trans Pacifc Partnership (TPP) dan membuka keran liberalisasi perdagangan dengan negara-negara anggotanya, maka posisi Indonesia dalam pasar dunia menjadi salah satu hal yang penting untuk didiskusikan. Hal ini dapat dilihat melalui kinerja perdagangan Indonesia di dalam pasar internasional, yang direpresentasikan dengan perubahan agregat ekspor dan agregat impor Indonesia di pasar dunia, pada masing-masing komoditas yang dijelaskan dalam sembilan sektor.

Sektor pertanian, peternakan, kehutanan dan perikanan terdiri dari 14 komoditas dalam GTAP. Beberapa komoditas menunjukkan kenaikan dua sisi, maksudnya kenaikan agregat ekspor Indonesia ke dunia disertai juga dengan kenaikan agregat impor ke Indonesia dari pasar dunia apabila Indonesia ikut andil dalam kerja sama Trans Pacific Partnership (TPP). Komoditas ini antara lain padi (paddy rice), gandum (cereal grains not elsewhere classified), sayur buah dan kacang (vegetables, Fruits, nuts), biji sawit (oil seeds), hasil panen lainnya (crops nec), dan hasil ternak domba, kambing dan kuda (Bovine cattle, sheep and goats, horses). Kenaikan agregat ekspor Indonesia ke dunia yang cukup besar dirasakan oleh komoditas padi (paddy rice) yakni sebesar 392,52 persen sedangkan kenaikan agregat impornya hanya sebesar 0,87 persen. Di sisi lain, terdapat komoditas terigu (wheat) yang justru menerima dampaknya pada penurunan masing-masing agregat ekspor dan agregat impor di pasar dunia.

Disisi lain, agregat ekspor Indonesia untuk komoditas gula tebu (sugar cone, sugar beet) dan susu mentah (raw milk) ke dunia mengalami kenaikan yang disertai dengan penurunan pada sisi agregat impor. Hal ini mengindikasikan bahwa akan terjadi perbaikan kinerja perdagangan pada kedua komoditas ini apabila kebijakan liberalisasi penuh Indonesia-TPP diberlakukan. Sementara itu, penyumbang memburuknya kinerja perdagangan Indonesia sektor pertanian apabila diberlakukannya kebijakan liberalisasi perdagangan IndonesiaTPP berasal dari lima komoditas yakni tanaman kebun (plant-based flowers), hasil produksi hewani lainnya (animal products nec), wol/bulu domba-sutera (Wool silk-wool cocoons), kehutanan (forestry) serta perikanan (fishing).

Komoditas batu bara (coal), minyak tanah/pelumas (oil), gas (gas), barang tambang mineral lainnya (minerals nec) dan minyak bumi (petroleum) termasuk dalam sektor pertambangan dan penggalian. Hampir semua komoditas dalam sektor ini akan memperoleh dampak liberalisasi perdagangan IndonesiaTPP pada penurunan agregat ekspor Indonesia di pasar dunia. Kenaikan agregat ekspor ke dunia hanya dialami oleh komoditas minyak tanah/pelumas (oil) saja sebesar 0,5 persen dan disertai berkurangnya agregat impor sebesar 1,13 persen. Jadi secara umum, kinerja perdagangan dari sektor pertambangan dan penggalian akan memburuk apabila kebijakan liberalisasi perdagangan Indonesia-TPP benarbenar diberlakukan.

Sektor industri pengolahan merupakan sektor terbesar yang melingkupi 23 komoditas dalam GTAP. Simulasi kebijakan dengan memberlakukannya liberalisasi perdagangan antara Indonesia dan Trans Pacific Partnership (TPP) akan berdampak pada perubahan agregat ekspor dan agregat impor Indonesia komoditas-komoditas tersebut di pasar global dengan pola yang bervariasi. Kenaikan terbesar ekspor agregat Indonesia di pasar dunia yakni pada komoditas pakaian jadi (wearing apparel) yang mencapai 81,29 persen lalu diikuti oleh komoditas minuman ringan dan tembakau (beverages and tobacco products) serta susu olahan (diary products) masing-masing sebesar 33,01 persen dan 30,78 persen. Sementara itu, 14 komoditas lainnya akan mengalami dampak penurunan pada nilai ekspor agregat ke pasar dunia. Dari sisi agregat impor yang masuk ke pasar Indonesia dari seluruh dunia, seluruh 
komoditas di sektor industri pengolahan mengalami kenaikan dengan persentase yang berbeda-beda. Kenaikan terbesar agregat impor terjadi pada komoditas tekstil (textiles) yakni sebesar 21,52 persen, tetapi diimbangi pula oleh kenaikan agregat ekspor Indonesia ke dunia sebesar 20,46 persen. Lalu, disusul kemudian komoditas/produk daging lainnya (bovine meat product), dan komoditas logam (metal products) yang masing-masing sebesar 19,54 persen dan 18,11 persen.

Pada sektor Listrik, Gas dan Air Bersih, setiap penurunan agregat ekspor tersebut dibarengi dengan kenaikan nilai agregat impor dari komoditas listrik (electricity), gas (gas manufacture and distribution), dan air (water) dari pasar dunia ke Indonesia. Berdasarkan hasil simulasi tersebut nampak bahwa setiap persentase penurunan agregat ekspor selalu lebih besar dibandingkan persentase kenaikan nilai agregat impornya.

Sektor konstruksi hanya terdiri komoditas konstruksi (construction) yang mengalami penurunan ekspor agregat dari Indonesia ke pasar dunia sebesar 4,51 persen. Sedangkan perubahan agregat impor pada komoditas ini mengarah ke arah positif yang artinya meningkat sebesar 3,52 persen.

Sektor keenam, yakni sektor perdagangan, hotel dan restoran hanya terdiri satu komoditas saja, yaitu perdagangan (trade). Apabila diberlakukan liberalisasi, dengan skema penghapusan tarif seluruhnya di pasar Indonesia-TPP, maka nilai agregat ekspor dari Indonesia ke dunia untuk sektor perdagangan akan turun sebesar 6,21 persen seiring dengan meningkatnya nilai agregat impor sebesar 3,22 persen dari Indonesia ke dunia.

Sektor Pengangkutan dan Komunikasi terdiri dari komoditas transportasi air (sea transport), transportasi udara (air transport), komunikasi (communication), dan transportasi lainnya (transport nec). Keempat komoditas tersebut memperoleh dampak liberalisasi perdagangan Indonesia-TPP dengan pola yang sama, yaitu nilai agregat ekspor Indonesia ke dunia menurun yang diiringi dengan meningkatnya nilai agregat impor Indonesia.

Agregat ekspor Indonesia ke dunia dari komoditas jasa keuangan lainnya (financial services nec), asuransi (insurance) dan layanan bisnis lainnya (business service nec) akan menurun masing-masing sebesar 6,72 persen, 6,66 persen dan 5,95 persen. Penurunan agregat ekspor ini juga disertai dengan peningkatan agregat impor atas ketiga komoditas tersebut masing-masing sebesar 3,32 persen, 2,07 persen, dan 1,38 persen. Dengan demikian sektor keuangan, persewaan dan jasa perusahaan justu akan dirugikan apabila Indonesia bergabung dengan Trans Pacific Partnership (TPP).

Ketiga komoditas pada sektor jasa-jasa ini diprediksikan akan mengalami perubahan agregat ekspor Indonesia ke dunia ke arah negatif yang disertai dengan kenaikan nilai agregat impor dari pasar internasional pada komoditas adminstrasi publik/pertahanan/ kesehatan/pendidikan (public administration/ defence/health/ education) dan komoditas pariwisata dan jasa lainnya (recreation and other service) masing-masing sebesar 2,92 persen dan 2,98 persen. Sementara itu, perubahan agregat impor pada sektor hunian (dwellings) searah dengan perubahan agregat ekspornya di pasar global. Oleh karena itu, dapat disimpulkan bahwa tidak ada komoditas di sektor jasa-jasa yang akan diuntungkan dengan adanya skema liberalisasi penuh aatara Indonesia dan Trans Pacific Partnership (TPP).

Berdasarkan analisis kinerja perdagangan seperti yang telah dijelaskan secara sektoral tersebut, dapat kita terima bahwa menurunnya neraca perdagangan Indonesia sejalan dengan menurunnya kinerja perdagangan Indonesia hampir di semua sektor. Akan tetapi, hal tersebut tidak cukup untuk mengatakan bahwa keterlibatan Indonesia ke dalam Trans Pacific Partnership (TPP) akan memberikan pengaruh yang negatif bagi Indonesia. Hal ini dikarenakan dampak positif maupun negatif terhadap kinerja perdagangan masing-masing 
sektor yang ditimbulkan dari keterlibatan tersebut mungkin saja memberikan peluang dan tantangan bagi masing-masing komoditas dan sektor dalam pasar global. Untuk itu, diperlukan analisis mengenai daya saing ekspor dari setiap komoditas agar dapat dirumuskan kebijakan perdagangan yang sesuai.

\section{Kemungkinan Dampak Keterlibatan}

Indonesia dalam Trans Pacific Partnership (TPP) terhadap Daya Saing Ekspor Indonesia

Secara umum, suatu negara akan diuntungkan dengan adanya liberalisasi perdagangan apabila setiap negara dapat mengalokasikan sumber daya yang dimilikinya pada sektor-sektor yang memiliki keunggulan komparatif. Dampak yang mungkin ditimbulkan apabila Indonesia terlibat dalam Trans Pacific Partnership (TPP) dianalisis dari segi daya saing ekspor berdasarkan nilai keunggulan komparatif dan posisi perdagangannya. Daya saing ekpsor setiap komoditas Indonesia dihitung menggunakan indeks Revealed Symmetric Comparative Advantage (RSCA) dan Trade Balance Index (TBI).

Hasil penghitungan RSCA menunjukkan beberapa komoditas Indonesia yang memiliki nilai lebih besar dari nol (RSCA $>0$ ), artinya komoditas tersebut memiliki keunggulan komparatif. Seperti yang tersaji dalam tabel berikut:

Tabel 1. Komoditas Indonesia yang Memiliki Keunggulan Komparatif

\begin{tabular}{llcc}
\hline Comprising & Komoditas & \multicolumn{2}{c}{ Nilai RSCA } \\
& & $\begin{array}{c}\text { Sebelum } \\
\text { Simulasi }\end{array}$ & Setelah Simulasi \\
\hline ocr & Crops Nec & 0,589 & 0,599 \\
oap & Animal Products nec & 0,119 & 0,106 \\
fsh & Fishing & 0,475 & 0,464 \\
coa & Coal & 0,912 & 0,909 \\
gas & Gas & 0,696 & 0,687 \\
omn & Minerals Nec & 0,697 & 0,690 \\
vol & Vegetable Oils And Fats & 0,897 & 0,891 \\
ofd & Food Products Nec & 0,151 & 0,143 \\
tex & Textiles & 0,351 & 0,410 \\
wap & Wearing Apparel & 0,414 & 0,600 \\
lea & Leather Products & 0,429 & 0,498 \\
lum & Wood Products & 0,494 & 0,472 \\
ppp & Paper Products, Publishing & 0,419 & 0,401 \\
nfm & Metals Nec & 0,241 & 0,201 \\
cmn & Communication & 0,161 & 0,125 \\
\hline
\end{tabular}

Sumber: data diolah

Hasil penghitungan RSCA menjelaskan perbedaan nilai keunggulan komparatif antara dua titik waktu, yakni periode sebelum dan setelah diberlakukan kebijakan liberalisasi perdagangan Indonesia-TPP. Secara umum, perubahan yang terjadi sebelum simulasi tidak membuat suatu komoditas tertentu menjadi tidak memiliki keunggulan komparatif setelah dilakukan simluasi liberalisasi perdagangan. Seperti yang nampak pada tabel di atas, perubahan hanya terjadi pada kenaikan nilai
RSCA yang mengindikasikan bahwa komoditas tersebut semakin unggul, ataupun penurunan indeks keunggulan komparatif (nilai RSCA) saja yang mengindikasikan bahwa komoditas tersebut keunggulannya semakin berkurang, tanpa mengubah status komoditas menjadi tidak unggul.

Komoditas yang semakin tinggi nilai keunggulan komparatifnya setelah simulasi kebijakan liberalisasi antara lain hasil panen lainnya (crops nec), tekstil (textiles), pakaian jadi 
(wearing apparel), dan kulit (leather products). Hal ini sejalan dengan perkiraan dampak terhadap kinerja perdagangan seperti yang telah dipaparkan sebelumnya, yakni untuk komoditas crops nec, wearing apparel dan leather products, peningkatan agregat ekspornya lebih besar dibandingkan dengan peningkatan agregat impornya di pasar dunia. Tetapi, komoditas tekstil (textiles) yang mengalami peningkatan nilai keunggulan komparatifnya justru kenaikan agregat impornya lebih besar dibanding dengan kenaikan agregat ekspornya.

Sementara itu, komoditas yang nilai keunggulan komparatifnya semakin turun jumlahnya lebih banyak, antara lain, produk hewani lainnya (animal products nec), perikanan (fishing), batu bara (coal), gas (gas), barang tambang mineral lainnya (minerals nec), minyak sayur/nabati (vegetable oils and fats), produk makanan lainnya (Food Products Nec), kayu (wood products), kertas (paper products, publishing), logam lainnya (metals nec), dan komunikasi (communication). Hal ini juga seiring dengan memburuknya kinerja perdagangan Indonesia ke dunia atas komoditas-komoditas yang keunggulan komparatifnya berkurang tersebut setelah kebijakan liberalisasi Indonesia-TPP diberlakukan.

Di sisi lain, komoditas yang memiliki nilai indeks RSCA kurang dari nol $(\mathrm{RSCA}<0)$ yang berarti komoditas tersebut tidak memiliki keunggulan komparatif tercatat sebanyak 39 komoditas dan sekitar 85 persen nilai RSCA nya semakin ke arah negatif.

Apabila dicermati, kelompok komoditas yang memiliki keunggulan komparatif dan tidak memiliki keunggulan komparatif pada kedua titik waktu, yakni sebelum dan sesudah simulasi tidak menunjukkan perubahan yang berarti. Tidak ada komoditas yang mengalami pergeseran, baik dari unggul komparatif menjadi tidak unggul komparatif, ataupun sebaliknya. Oleh karena itu, analisis selanjutnya perlu memperhitungkan Trade Balance Index (TBI) untuk memetakan masing-masing komoditas tersebut yakni dengan melihat posisi suatu negara apakah sebagai net exportir atau net importir di dalam product mapping.

Berdasarkan nilai dari Revealed Symmetric Comparative Advantage (RSCA) dan Trade Balances Index (TBI) yang telah dihitung, posisi ekspor impor suatu negara dapat ditentukan dalam struktur product mapping yang dikelompokkan menjadi empat kategori. Kategori A merupakan komoditas yang memiliki keunggulan komparatif dan Negara tersebut menjadi eksportir untuk komoditas tersebut. Kategori A ini merupakan komoditas yang memiliki nilai RSCA $>0$ dan nilai TBI $>0$ serta merupakan posisi paling bagus dalam struktur product mapping. Komoditas yang termasuk dalam kategori B merupakan komoditas yang memiliki keunggulan komparatif tetapi Negara tersebut sebagai netimportir yang ditunjukkan dengan nilai RSCA $>0$ tetapi nilai $\mathrm{TBI}<0$. Selanjutnya, komoditas dikatakan termasuk kategori $\mathrm{C}$ ketika nilai RSCA $<0$ tetapi nilai TBI $>0$, yang berarti bahwa suatu Negara mengekspor komoditas tersebut meskipun sebenarnya tidak memiliki keunggulan komparatif di dalamnya. Dan terakhir, untuk kategori D apabila nilai RSCA < 0 dan TBI $<0$, maksudnya suatu negara merupakan net importir atas suatu komoditas yang tidak memiliki keunggulan komparatif.

Pengelompokan ke dalam product mapping yang telah dilakukan menghasilkan beberapa komoditas Indonesia yang memiliki keunggulan komparatif dan Indonesia merupakan net-eksportir atas komoditas tersebut. 
Tabel 2. Komoditas Indonesia Kategori A

\begin{tabular}{cccc}
\hline Comprising & Komoditas & Sebelum Simulasi & Setelah Simulasi \\
\hline ocr & Crops nec & A & A \\
\hline oap & Animal products nec & A & A \\
\hline fsh & Fishing & A & A \\
\hline coa & Coal & A & A \\
\hline gas & Gas & A & A \\
\hline omn & Minerals nec & A & A \\
\hline vol & Vegetable oils and fats & A & A \\
\hline ofd & Food products nec & A & A \\
\hline tex & Textiles & A & A \\
\hline wap & Wearing apparel & A & A \\
\hline lea & Leather products & A & A \\
\hline lum & Wood products & A & A \\
\hline ppp & Paper products, publishing & A & A \\
\hline nfm & Metals nec & A & A \\
\hline cmn & communication & &
\end{tabular}

Sumber: data diolah

Komoditas yang termasuk dalam kategori A menunjukkan bahwa komoditas tersebut memiliki keunggulan komparatif dan konsisten pada kedua titik waktu yakni sebelum dan setelah simulasi kebijakan perdaganan bebasa Indonesia-TPP diberlakukan. Konsistensi tersebut mengindikasikan bahwa komoditaskomoditas tersebut potensial dan siap untuk bersaing di pasar global apabila Indonesia bergabung dengan Trans Pacific Partnership (TPP) dan memberlakukan kebijakan liberalisasi penuh.

Sementara itu, dari penghitungan nilai RSCA dan TBI dihasilkan juga beberapa komoditas Indonesia yang memiliki keunggulan komparatif tetapi Indonesia justru menjadi net exporter atas komoditas tersebut. Komoditas dalam kelompok ini dimasukkan dalam kategori C. Artinya, meskipun komoditas ini tidak unggul secara komparatif, tetapi Indonesia masih dapat menjadi eksportir ke pasar dunia. Komoditas Indonesia seperti hasil hutan (forestry), tembakau (Beverages and tobacco products), karet dan plastik (Chemical, rubber, plastic products), produk mineral lainnya (Mineral products nec), produk industri lainnya (Manufactures nec), industri gas dan distribusinya (Gas manufacture and distribution), serta transportasi air (Sea transport) tidak memiliki keunggulan komparatif tetapi Indonesia berperan sebagai net exporter di pasar dunia, baik sebelum simulasi maupun setelah simulasi kebijakan liberalisasi penuh IndonesiaTPP.

Selain komoditas-komoditas yang termasuk ke dalam kategori A dan C, sebagian besar komoditas Indonesia termasuk dalam kategori D. Tercatat sebanyak 30 komoditas, atau sekitar 52,6 persen dari total komoditas Indonesia termasuk dalam kategori D. Hal ini menunjukkan bahwa sebagian besar komoditas Indonesia tidak memiliki keunggulan komparatif dan Indonesia berperan sebagai net importer atas komoditas-komoditas tersebut. Artinya, sebelum dan sesudah perdagangan Indonesia-TPP diliberalisasi, masih banyak komoditas Indonesia yang tidak mampu bersaing di pasar internasional. Komposisi komoditas yang telah dikategorikan berdasarkan penghitungan RSCA dan TBI ditampilkan dalam gambar 3 . 


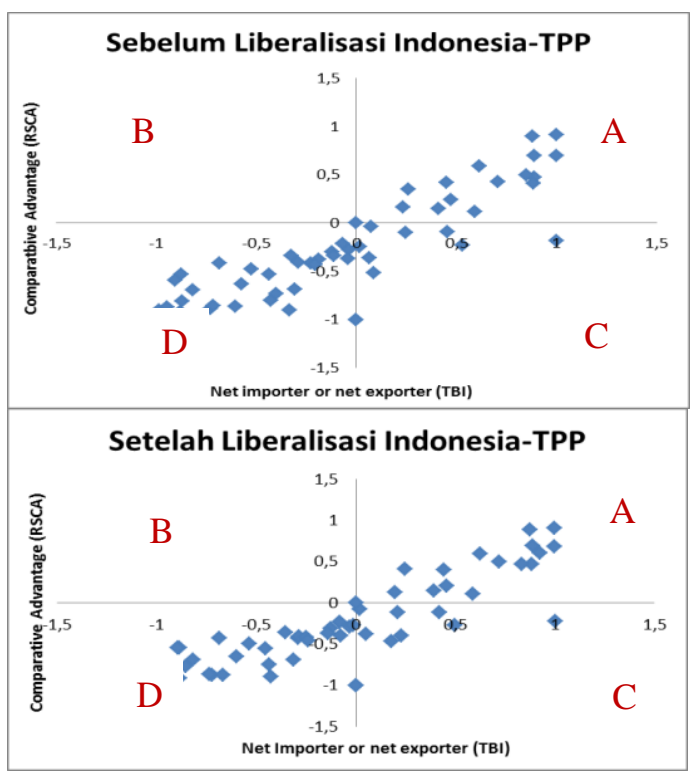

Sumber: diolah

\section{Gambar 3. Plot Product Mapping Komoditas Indonesia}

Trend komoditas Indonesia dari periode sebelum simulasi dibandingkan dengan periode setelah simulasi tidak menunjukkan adanya perubahan yang besar. Sebagian besar komoditas Indonesia termasuk dalam kategori D (30/57 komoditas) sekitar 52,6 persen. Sedangkan komoditas dalam kategori A (15/57 komoditas) sekitar 26,3 persen. Dalam penelitian ini, terdapat tiga komoditas yang tidak terdefinisikan yakni Sugar cone, sugar beet (c_b), Electricity (ely) dan hunian/dwellings (dwe).

Pergeseran kategorisasi hanya terjadi pada dua komoditas, yakni padi/paddy rice (pdr) dan peralatan elektronik/electronic equipment (ele). Komoditas padi menunjukkan perkembangan ke arah yang lebih baik dari segi Trade Balance Index (TBI). Awalnya, sebelum kebijakan liberalisasi penuh Indonesia-TPP diberlakukan, komoditas padi termasuk dalam kategori D di dalam product mapping. Artinya komoditas padi tidak memiliki keunggulan komparatif serta Indonesia berperan sebagai net importer atas komoditas tersebut. Lalu, ketika diberlakukan kebijakan liberalisasi penuh dalam simulasi, akan berdampak pada pergerseran komoditas padi ke kategori $C$, yang berarti bahwa setelah kebijakan liberalisasi penuh Indonesia-TPP, Indonesia akan berperan sebagai net exporter padi, meskipun komoditas tersebut tidak memiliki keunggulan komparatif.

Lain halnya dengan komoditas peralatan elektronik (ele) yang juga mengalami pergeseran dari periode sebelum dan setelah simulasi liberalisasi Indonesia-TPP. Namun, pergeseran tersebut justru menunjukkan kemunduran. Sebelum dilakukan simulasi kebijakan liberalisasi penuh, untuk komoditas peralatan elektronik (ele) Indonesia berperan sebagai net exporter yang dicerminkan oleh nilai TBI > 0, meskipun komoditas ele tersebut tidak memiliki keunggulan komparatif. Artinya, sebelum simulasi komoditas ini termasuk dalam kategori C. Lalu, setelah simulasi kebijakan liberalisasi Indonesia-TPP diberlakukan, Indonesia justru akan menjadi net importer atas komoditas ele yang tidak memiliki keunggulan komparatig ini sehingga membuat komoditas ini bergeser ke kategori D.

Penghitungan indeks keunggulan komparatif tersebut menghasilkan lima komoditas unggulan yang diperkirakan akan dapat bersaing apabila Indonesia bergabung menjadi anggota Trans Pacific Partnership (TPP). Kelima komoditas unggulan tersebut disajikan dalam tabel 4.

Tabel 4. Top 5 Komoditas Indonesia

\begin{tabular}{lc}
\hline Comprising & Komoditas \\
\hline coa & Coal \\
\hline vol & vegetable oils and fats \\
\hline omn & minerals nec \\
\hline gas & gas \\
\hline wap & wearing apparel \\
\hline
\end{tabular}

Sumber: data diolah 
Komoditas unggulan Indonesia tersebut berasal dari sektor pertambangan dan penggalian, dan sektor industri pengolahan. Di sektor pertambangan dan penggalian, batu bara (coal) menempati posisi pertama dengan indeks keunggulan komparatif tertinggi. Dari sektor pertambangan, komoditas lainnya adalah komoditas barang tambang mineral lainnya (minerals nec) dan komoditas gas (gas) masingmasing di posisi ketiga dan keempat. Dari sektor industri pengolahan, daya saing yang tinggi dicerminkan oleh indeks keunggulan komparatifnya diwakili oleh komoditas minyak dan lemak nabati (vegetable oils and fats) di peringkat dua dan komoditas pakaian jadi (wearing apparel) pada posisi kelima.

\section{SIMPULAN}

Penelitian ini bertujuan untuk menganalisis kemungkinan dampak yang ditimbulkan apabila Indonesia bergabung dengan Trans Pacific Partnership (TPP) terhadap kinerja perdagangan secara sektoral dan daya saing ekspor Indonesia. Berdasarkan hasil analisis, bergabungnya Indonesia dalam Trans Pacific Partnership (TPP) akan berakibat pada turunnya neraca perdagangan Indonesia dan negara-negara anggota TPP sedangkan negara non anggota TPP (Rest of the World) justru akan diuntungkan dengan meningkatnya neraca perdagangan.

Turunnya neraca perdagangan Indonesia dijelaskan oleh perubahan nilai agregat ekspor dan agregat impor Indonesia di pasar dunia ke dalam sembilan sektor. Sektor yang digolongkan antara lain sektor pertanian, peternakan, kehutanan, dan perikanan; sektor pertambangan dan penggalian; sektor industri pengolahan; sektor listrik, gas dan air bersih; sektor konstruksi; sektor perdagangan; sektor pengangkutan dan komunikasi; sektor keuangan. Real estat dan jasa perusahaan; serta sektor jasa-jasa. Secara umum, semua sektor yang ada mengalami penurunan kinerja perdagangan yang tercermin dari persentase peningkatan agregat impor Indonesia dari dunia yang lebih besar dibandingkan dengan persentase peningkatan agregat ekspor Indonesia ke pasar dunia.
Daya saing setiap komoditas Indonesia sebelum dan setelah diberlakukan simulasi kebijakan perdagangan bebas Indonesia-TPP diukur dengan menggunakan Revealed Symmetric Comparative Advantage (RSCA) dan Trade Balance Index (TBI) yang memungkinkan setiap komoditas dikategorikan dalam struktur product mapping. Berdasarkan penghitungan RSCA, didapatkan 15 komoditas Indonesia (26,3 persen) memiliki keunggulan komparatif. Sedangkan komoditas yang tidak memiliki keunggulan komparatif tercatat sebanyak 39 komoditas (68,4 persen).

Dalam struktur product mapping, komoditas Indonesia pada periode baik sebelum maupun setelah simulasi perdagangan bebas IndonesiaTPP, yang termasuk dalam kategori A tercatat sebanyak 15 komoditas, kategori $\mathrm{C}$ sebanyak 7 komoditas, dan kategori D sebanyak 30 komoditas. Pergeseran kategorisasi hanya terjadi pada komoditas padi (paddy rice) dari kategori D sebelum simulasi ke kategori C setelah simulasi, serta komoditas peralatan elektronik (electronic equipment) dari sebelum simulasi termasuk kategori C bergeser ke kategori $\mathrm{D}$ setelah dilakukan simulasi perdagangan bebas Indonesia-TPP.

Berdasarkan hasil penghitungan RSCA, didapatkan lima komoditas unggulan (top five products) Indonesia yang diperkirakan akan mampu bersaing dan menjadi primadona apabila dilakukan liberalisasi perdagangan Indonesia-TPP. Kelima komoditas tersebut antara lain batu bara (coal), minyak dan lemak nabati (vegetable oils and fats), barang tambang mineral lainnya (minerals nec), gas (gas), dan pakaian jadi (wearing apparel).

Berdasarkan hasil pembahasan tersebut, keterlibatan Indonesia dalam TPP memungkinkan adanya pengaruh yang negatif dalam kinerja perdagangan Indonesia. Selain itu pula hanya sebagian kecil komoditas ekspor Indonesia yang mampu bersaing apabila liberalisasi perdagangan Indonesia-TPP benarbenar diberlakukan. Oleh karena itu, dapat ditarik kesimpulan bahwa setiap negara, khususnya Indonesia perlu hati-hati dalam memutuskan untuk bergabung dalam suatu kerja sama internasional agar kebijakan yang diambil dapat mewujudkan kesejahteraan masyarakat yang selaras dengan maqashid syariah. 


\section{Implikasi Kebijakan}

Dampak yang mungkin ditimbulkan apabila Indonesia bergabung dalam Trans Pacific Partnership (TPP) adalah menurunnya neraca perdagangan Indonesia. Untuk itu, diperlukan adanya kebijakan yang efektif untuk menjaga dan memperbaiki kinerja perdagangan Indonesia. Perlu dilakukan peningkatan kapasitas produksi pada komoditas-komoditas yang diperkirakan mengalami peningkatan agregat ekspor ke pasar dunia. Mendukung komoditas Indonesia yang memiliki daya saing sebagai leading exported products dari Indonesia ke pasar dunia. Hal ini dapat dilakukan dengan mendorong produksi yang lebih efisien, transfer ilmu dan teknologi dari negara-negara anggota Trans Pacifif Partnership (TPP).

\section{Keterbatasan Penelitian}

Shock yang digunakan dalam penelitian ini hanya didasarkan pada liberalisasi hambatan perdagangan dari sisi tarif perdagangan. Sementara itu, kerjasama Trans Pacific Partnership (TPP) merupakan suatu kesepakatan komprehensif yang tidak hanya mengatur perdagangan barang dan jasa, tetapi juga investasi, hukum, hak kekayaan intelektual dan aspek lainnya diantara negara-negara anggota.

Penelitian ini menggunakan GTAP standar versi 8 dengan tahun dasar 2007 sehingga analisisnya bersifat statik-komparatif. Tahun dasar yang digunakan juga memungkinkan adanya perbedaan pada aspek ekonomi dan perdagangan dengan kondisi saat ini. Oleh karena itu, untuk penelitian selanjutnya lebih baik menggunakan GTAP dengan model dinamis dan versi terbaru yakni versi 9 yang dirilis pada tahun 2015 agar menghasilkan prediksi yang lebih mendekati kondisi yang sebenarnya.

\section{DAFTAR PUSTAKA}

Aichele, R., \& Felbermayr, G. (2015, October 8). The Trans-Pacific Partnership Deal (TPP): What are the economic consequences for in- and outsiders. Global Economic Dynamics Focus Paper, 8--9.

Chapra, Umer. (2000). The Future of Economics: An Islamic Perspective. Leicester: The Islamic Foundation.

Laursen, K. (2000). Trade specialisation, technology and growth: theory and evidence from advanced countries. Cheltenham, UK and Lyme, US: Edward Elgar.

Vollrath, T. (1991). A Theoretical Evaluation of Alternative Trade Intensity Measures of Revealed Comparative Advantage. Weltwirtschaftliches Archiv, 265-280.

Widodo, T. (2009). Comparative Advantage: Theory, Empirical Measures and Case Studies. Review of Economic and Business Studies, 57-82.

Widodo, T. (2010). International Trade, Regionalism and Dynamic Market (Pertama ed.). Yogyakarta, Indonesia: BPFE.

Worz, J. (2005). Dynamic of Trade Specialization in Developed and Less Developed Countries. Emerging Markets Finance and Trade, 92-122. 


\section{LAMPIRAN}

Tabel 1. Perubahan Agregat Ekspor dan Agregat Impor

\begin{tabular}{|c|c|c|c|}
\hline \multirow{2}{*}{ Komoditas dalam GTAP } & \multirow{2}{*}{ Kode } & \multicolumn{2}{|c|}{ Hasil Simulasi } \\
\hline & & Agregat Ekspor & Agregat Impor \\
\hline \multicolumn{4}{|c|}{ Sektor Pertanian, Peternakan, Kehutanan dan Perikanan } \\
\hline Paddy rice & pdr & 392,52 & 0,87 \\
\hline Wheat & wht & $-3,02$ & $-0,22$ \\
\hline Cereal grains not elsewhere classified (nec) & gro & 0,94 & 1,27 \\
\hline Vegetables, Fruits, nuts & v_f & 1,73 & 2,46 \\
\hline Oil seeds & osd & 3,73 & 4,93 \\
\hline Sugar cone, sugar beet & $c \_b$ & 8,46 & $-9,68$ \\
\hline Plant-based flowers & $\mathrm{pfb}$ & $-18,24$ & 47,69 \\
\hline Crops nec & ocr & 7,28 & 3,30 \\
\hline Bovine cattle, sheep and goats, horses & $\mathrm{ctl}$ & 4,30 & 6,97 \\
\hline Animal products nec & oap & $-0,72$ & 3,23 \\
\hline Raw milk & rmk & 0,71 & $-0,76$ \\
\hline Wool silk-wool cocoons & wol & $-0,85$ & 23,30 \\
\hline Forestry & frs & $-7,95$ & 3,49 \\
\hline Fishing & fsh & $-1,19$ & 3,39 \\
\hline \multicolumn{4}{|c|}{ Sektor Pertambangan dan Penggalian } \\
\hline Coal & coa & $-0,84$ & 6,89 \\
\hline Oil & oil & 0,50 & $-1,13$ \\
\hline Gas & gas & $-0,62$ & $-0,45$ \\
\hline Minerals nec & omn & $-0,80$ & 1,18 \\
\hline Petroleum, coal product & p_c & $-0,06$ & 2,02 \\
\hline \multicolumn{4}{|c|}{ Sektor Industri Pengolahan } \\
\hline Bovine meat product & $\mathrm{cmt}$ & $-2,25$ & 19,54 \\
\hline Meat products nec & omt & $-10,88$ & 16,05 \\
\hline Vegetable oils and fats & vol & $-3,95$ & 1,35 \\
\hline Dairy products & mil & 30,78 & 10,08 \\
\hline Processed rice & pcr & $-1,46$ & 17,36 \\
\hline Sugar & sgr & 20,57 & 11,78 \\
\hline Food products nec & ofd & 1,43 & 10,49 \\
\hline Beverages and tobacco products & b_t & 33,01 & 15,42 \\
\hline Textiles & tex & 20,46 & 21,52 \\
\hline Wearing apparel & wap & 81,29 & 9,14 \\
\hline Leather products & lea & 25,32 & 17,06 \\
\hline Wood products & lum & $-3,70$ & 8,32 \\
\hline Paper products, publishing & ppp & $-2,16$ & 2,15 \\
\hline Chemical, rubber, plastic product & crp & $-4,28$ & 10,54 \\
\hline Mineral products nec & $\mathrm{nmm}$ & $-1,69$ & 8,82 \\
\hline Ferrous metals & i_s & $-3,98$ & 1,78 \\
\hline Metals nec & $\mathrm{nfm}$ & $-6,16$ & 0,13 \\
\hline Metal products & fmp & $-0,07$ & 18,11 \\
\hline Motor vehicles and parts & mvh & 2,86 & 15,21 \\
\hline Transport equipment nec & otn & $-4,20$ & 1,68 \\
\hline Electronic equipment & ele & $-4,25$ & 1,29 \\
\hline Machinery and equipment nec & ome & 1,15 & 2,07 \\
\hline Manufactures nec & omf & $-3,59$ & 9,00 \\
\hline \multicolumn{4}{|c|}{ Sektor Listrik, Gas dan Air Bersih } \\
\hline Electricity & ely & $-2,87$ & 1,24 \\
\hline Gas manufacture and distribution & gdt & $-7,86$ & 2,51 \\
\hline Water & wtr & $-7,22$ & 2,52 \\
\hline \multicolumn{4}{|c|}{ Sektor Konstruksi } \\
\hline Construction & cns & $-4,51$ & 3,52 \\
\hline \multicolumn{4}{|c|}{ Sektor Perdagangan, Hotel dan Restoran } \\
\hline Trade & $\operatorname{trd}$ & $-6,21$ & 3,22 \\
\hline \multicolumn{4}{|c|}{ Sektor Pengangkutan dan Komunikasi } \\
\hline Sea transport & wtp & $-2,77$ & 1,16 \\
\hline Air transport & atp & $-2,18$ & 0,92 \\
\hline
\end{tabular}




\begin{tabular}{|c|c|c|c|}
\hline Communication & $\mathrm{cmn}$ & $-6,69$ & 3,05 \\
\hline Transport nec & otp & $-4,73$ & 1,95 \\
\hline \multicolumn{4}{|c|}{ Sektor Keuangan, Persewaan \& Jasa Perusahaan } \\
\hline Financial services nec & ofi & $-6,72$ & 3,32 \\
\hline Insurance & isr & $-6,66$ & 2,07 \\
\hline Business service nec & obs & $-5,95$ & 1,38 \\
\hline \multicolumn{4}{|c|}{ Sektor Jasa-jasa } \\
\hline Public administration/defence/health/education & osg & $-5,99$ & 2,92 \\
\hline Dwellings & dwe & $-0,44$ & $-0,44$ \\
\hline Recreation and other service & ros & $-6,18$ & 2,98 \\
\hline
\end{tabular}

\section{Sumber: database GTAP versi 8}

\begin{tabular}{|c|c|c|c|c|}
\hline \multirow{2}{*}{ Komodias } & \multirow{2}{*}{$\begin{array}{c}\text { Perubahan agregat } \\
\text { ekspor }\end{array}$} & \multirow[b]{2}{*}{ Perubahan agregat impor } & \multicolumn{2}{|c|}{ Kategorisasi } \\
\hline & & & Sebelum Simulasi & Setelah Simulasi \\
\hline $\mathrm{pdr}$ & 392,5182 & 0,8747 & $\mathrm{D}$ & $\mathrm{C}$ \\
\hline wht & $-3,0233$ & $-0,2178$ & $\mathrm{D}$ & $\mathrm{D}$ \\
\hline gro & 0,941 & 1,2736 & $\mathrm{D}$ & $\mathrm{D}$ \\
\hline$v_{-} f$ & 1,7322 & 2,4609 & $\mathrm{D}$ & $\mathrm{D}$ \\
\hline osd & 3,7302 & 4,9345 & $\mathrm{D}$ & $\mathrm{D}$ \\
\hline c_b & 8,4556 & $-9,6812$ & \#DIV/0! & \#DIV/0! \\
\hline $\mathrm{pfb}$ & $-18,2399$ & 47,6929 & $\mathrm{D}$ & $\mathrm{D}$ \\
\hline ocr & 7,2803 & 3,2982 & $\mathrm{~A}$ & $\mathrm{~A}$ \\
\hline ctl & 4,3009 & 6,9733 & $\mathrm{D}$ & $\mathrm{D}$ \\
\hline oap & $-0,7165$ & 3,2304 & $\mathrm{~A}$ & $\mathrm{~A}$ \\
\hline $\mathrm{rmk}$ & 0,7094 & $-0,756$ & $\mathrm{D}$ & $\mathrm{D}$ \\
\hline wol & $-0,8547$ & 23,3027 & $\mathrm{D}$ & $\mathrm{D}$ \\
\hline frs & $-7,9483$ & 3,4911 & $\mathrm{C}$ & $\mathrm{C}$ \\
\hline fsh & $-1,1875$ & 3,3942 & $\mathrm{~A}$ & $\mathrm{~A}$ \\
\hline coa & $-0,8406$ & 6,8902 & $\mathrm{~A}$ & $\mathrm{~A}$ \\
\hline oil & 0,5028 & $-1,1296$ & $\mathrm{D}$ & $\mathrm{D}$ \\
\hline gas & $-0,6248$ & $-0,4516$ & $\mathrm{~A}$ & $\mathrm{~A}$ \\
\hline omn & $-0,7986$ & 1,1833 & $\mathrm{~A}$ & $\mathrm{~A}$ \\
\hline $\mathrm{cmt}$ & $-2,2475$ & 19,5426 & $\mathrm{D}$ & $\mathrm{D}$ \\
\hline omt & $-10,8804$ & 16,0547 & $\mathrm{D}$ & $\mathrm{D}$ \\
\hline vol & $-3,95$ & 1,3482 & $\mathrm{~A}$ & $\mathrm{~A}$ \\
\hline $\mathrm{mil}$ & 30,7803 & 10,0782 & $\mathrm{D}$ & $\mathrm{D}$ \\
\hline pcr & $-1,4625$ & 17,3587 & $\mathrm{D}$ & $\mathrm{D}$ \\
\hline sgr & 20,5693 & 11,7801 & $\mathrm{D}$ & $\mathrm{D}$ \\
\hline ofd & 1,4323 & 10,4929 & $\mathrm{~A}$ & $\mathrm{~A}$ \\
\hline b_t & 33,0107 & 15,4154 & C & C \\
\hline tex & 20,4628 & 21,5209 & $\mathrm{~A}$ & $\mathrm{~A}$ \\
\hline wap & 81,2903 & 9,1413 & $\mathrm{~A}$ & $\mathrm{~A}$ \\
\hline lea & 25,3178 & 17,0639 & $\mathrm{~A}$ & $\mathrm{~A}$ \\
\hline lum & $-3,6962$ & 8,3152 & $\mathrm{~A}$ & $\mathrm{~A}$ \\
\hline ppp & $-2,1634$ & 2,1533 & $\mathrm{~A}$ & $\mathrm{~A}$ \\
\hline p_c & $-0,0616$ & 2,0222 & $\mathrm{D}$ & $\mathrm{D}$ \\
\hline crp & $-4,283$ & 10,5426 & $\mathrm{C}$ & $\mathrm{C}$ \\
\hline $\mathrm{nmm}$ & $-1,6908$ & 8,8156 & C & C \\
\hline i_s & $-3,9761$ & 1,7817 & $\mathrm{D}$ & $\mathrm{D}$ \\
\hline $\mathrm{nfm}$ & $-6,1567$ & 0,1308 & $\mathrm{~A}$ & $\mathrm{~A}$ \\
\hline $\mathrm{fmp}$ & $-0,0689$ & 18,1092 & $\mathrm{D}$ & $\mathrm{D}$ \\
\hline $\mathrm{mvh}$ & 2,8574 & 15,2129 & $\mathrm{D}$ & $\mathrm{D}$ \\
\hline otn & $-4,1952$ & 1,6796 & $\mathrm{D}$ & $\mathrm{D}$ \\
\hline ele & $-4,2517$ & 1,291 & $\mathrm{C}$ & $\mathrm{D}$ \\
\hline ome & 1,1534 & 2,0724 & $\mathrm{D}$ & $\mathrm{D}$ \\
\hline omf & $-3,5933$ & 8,9957 & $\mathrm{C}$ & $\mathrm{C}$ \\
\hline ely & $-2,8725$ & 1,2421 & \#DIV/0! & \#DIV/0! \\
\hline $\mathrm{gdt}$ & $-7,8576$ & 2,5063 & C & C \\
\hline wtr & $-7,2191$ & 2,5161 & $\mathrm{D}$ & $\mathrm{D}$ \\
\hline cns & $-4,5075$ & 3,5225 & $\mathrm{D}$ & $\mathrm{D}$ \\
\hline
\end{tabular}




\begin{tabular}{|c|c|c|c|c|}
\hline \multirow{2}{*}{ Komodias } & \multirow{2}{*}{$\begin{array}{c}\text { Perubahan agregat } \\
\text { ekspor }\end{array}$} & \multirow[b]{2}{*}{ Perubahan agregat impor } & \multicolumn{2}{|c|}{ Kategorisasi } \\
\hline & & & Sebelum Simulasi & Setelah Simulasi \\
\hline $\operatorname{trd}$ & $-6,2085$ & 3,2175 & $\mathrm{D}$ & $\mathrm{D}$ \\
\hline otp & $-4,7314$ & 1,9535 & $\mathrm{D}$ & $\mathrm{D}$ \\
\hline wtp & $-2,7656$ & 1,1602 & C & $\mathrm{C}$ \\
\hline atp & $-2,1776$ & 0,9223 & $\mathrm{D}$ & $\mathrm{D}$ \\
\hline $\mathrm{cmn}$ & $-6,6882$ & 3,0537 & A & $\mathrm{A}$ \\
\hline ofi & $-6,7188$ & 3,3182 & $\mathrm{D}$ & $\mathrm{D}$ \\
\hline isr & $-6,6553$ & 2,0669 & $\mathrm{D}$ & $\mathrm{D}$ \\
\hline obs & $-5,9503$ & 1,3777 & $\mathrm{D}$ & $\mathrm{D}$ \\
\hline ros & $-6,1826$ & 2,9849 & $\mathrm{D}$ & $\mathrm{D}$ \\
\hline osg & $-5,9896$ & 2,9184 & $\mathrm{D}$ & $\mathrm{D}$ \\
\hline dwe & $-0,4398$ & $-0,4398$ & \#DIV/0! & \#VALUE! \\
\hline
\end{tabular}

